\title{
HUBUNGAN STATUS GIZI DAN USIA MENARCHE DENGAN DISMENORHEA PRIMER PADA REMAJA PUTRI KELAS XI SMA NEGERI 15 PALEMBANG
}

\author{
Eka Rahmadhayanti ${ }^{1}$, Anur Rohmin ${ }^{2}$ \\ 1,2 Program Studi D III Kebidanan, STIK Siti Khadijah Palembang \\ Email: eka.rahmadhayanti@yahoo.co.id
}

\begin{abstract}
The Correlation Between Nutrition Status and Menarche Age with Primary Dysmenorrhea in Teenage Girl Second Grade Students of SMAN 15 Palembang. Primary dysmenorrhea is menstruation pain that occurred since menarche and found no abnormality of the uterus or other organs which disturbing the activities of teens. This study was to find out the correlation between nutrition status and menarche age with primary dysmenorrhea in teenage girl second grade students of SMAN 15 Palembang, 2016. The research was an analytical survey design through cross sectional approach. The research was done by using 75 respondents and taken with stratified random sampling. Data were analyzed by univariate and bivariate analysis with Chi square methods. The results showed that there were 61 respondents $(81.3 \%)$ who experience primary dysmenorrhea and 14 respondents (18.7\%) who did not experience primary dysmenorrhea. The result showed that there was correlation between nutrition status and menarche age with primary dysmenorrhea with value ( $\mathrm{p}$ value $=0.046$ and 0.018 ), it can be concluded that nutrition status and menarche age were significantly related to the incidence of primary dysmenorrhea.
\end{abstract}

Keywords: Primary dysmenorrhea, Nutrition status, Menarche age

\begin{abstract}
Abstrak: Hubungan Status Gizi dan Usia Menarche dengan Dismenorhea Primer pada Remaja Putri Kelas XI SMA Negeri 15 Palembang. Dismenorhea primer adalah nyeri menstruasi yang mulai terasa sejak menarche dan tidak ditemukan kelainan dari alat kandungan atau organ lainnya yang berdampak menganggu aktivitas remaja. Tujuan: diketahuinya hubungan status gizi dan usia menarche dengan dismenorhea primer pada remaja putri kelas XI SMA Negeri 15 Palembang Tahun 2016. Penelitian ini menggunakan metode survey analitik dengan pendekatan cross sectional. Besar sampel adalah 75 responden diambil dengan teknik stratified random sampling. Analisis data yang digunakan adalah analisis univariat dan bivariat dengan menggunakan uji statistik chi-square. Hasil penelitian menunjukkan bahwa terdapat 61 responden $(81,3 \%)$ yang mengalami dismenorhea primer dan 14 responden $(18,7 \%)$ yang tidak mengalami dismenorhea primer. Hasil menunujukan bahwa terdapat hubungan antara status gizi dan usia menarche dengan dismenorhea primer dengan nilai ( $p$-value $=0,046$ dan 0.018 ), ada hubungan antara status gizi dan usia menarche dengan kejadian dismenorhea primer.
\end{abstract}

Kata kunci: Dismenorhea primer, Status gizi, Usia menarche

Dismenorhea adalah nyeri sewaktu haid. Dismenorhea terdiri dari gejala yang kompleks berupa kram perut bagian bawah yang menjalar ke punggung. Dismenorhea dapat diklasifikasikan menjadi dua, yaitu dismenorhea primer dan dismenorhea sekunder. Dismenorhea primer adalah dismenorhea yang mulai terasa sejak menarche dan tidak ditemukan kelainan dari alat kandungan atau organ lainnya yang berdampak dapat mengganggu aktivitas remaja, sedangkan dismenorhea sekunder biasanya terjadi kemudian setelah menarche yang disebabkan oleh endometriosis, fibroid, IUD, tumor pada tuba fallopi, polip uteri dan lain-lain (Dewi, 2012).
Faktor resiko yang menyebabkan terjadinya dismenorhea primer diantaranya yaitu usia menarche yang cepat yaitu $<12$ tahun, riwayat ibu atau saudara kandung yang mengalami dismenorhea, overweight, atupun obese. Daftary dan Patky (2008) menyatakan bahwa overweight dan obese membawa peranan sebagai faktor terjadinya dismenorhea primer.

Dismenorhea primer terjadi pada $90 \%$ wanita dan biasanya terasa setelah mereka menarche dan berlanjut hingga usia pertengahan 20-an atau hingga mereka memiliki anak. Sekitar $10 \%$ penderita dismenorhea tidak dapat mengikuti kegiatan sehari-hari. Gejalanya mulai terasa pada 1 atau 2 hari sebelum haid dan 
berakhir setelah haid dimulai. Biasanya nyeri berakhir setelah diberi kompres panas atau oleh pemberian analgesik (Dewi, 2012).

Riwayat menstruasi mempengaruhi risiko mengalami dismenorhea. Akan tetapi, banyak pakar masih berdebat tentang seberapa penting perannya secara keseluruhan.Usia menarche yang terlalu muda ( $₫ 2$ tahun) dimana organ-organ reproduksi belum berkembang secara maksimal dan masih terjadi penyempitan pada leher rahim, maka akan timbul rasa sakit pada saat menstruasi. karena organ reproduksi wanita belum berfungsi secara maksimal (Rosenthal, 2013). Usia menarche bervariasi pada setiap individu dan wilayah tempat tinggal, namun usia menarche dapat dikatakan normal apabila terjadi pada usia 12-14 tahun (Susanti, 2012).

Status gizi merupakan salah satu faktor resiko terjadinya dismenore primer, status gizi yang rendah (underweight) dapat diakibatkan karena asupan makanan yang kurang, termasuk zat besi yang dapat menimbulkan anemia. Anemia merupakan salah satu faktor yang menyebabkan kurangnya daya tahan tubuh terhadap rasa nyeri sehingga saat menstruasi dapat terjadi dismenore primer, sedangkan status gizi lebih (overweight) dapat juga mengakibatkan dismenore karena terdapat jaringan lemak yang berlebihan yang dapat mengakibatkan hiperplasi pembuluh darah atau terdesaknya pembuluh darah oleh jaringan lemak pada organ reproduksi wanita, sehingga darah yang seharusnya mengalir pada proses menstruasi terganggu dan mengakibatkan nyeri pada saat menstruasi (Kusmiran, 2011).

Angka kejadian nyeri menstruasi di dunia sangat besar. Lebih dari 50\% perempuan di setiap Negara mengalami nyeri menstruasi. Di Amerika angka persentasenya sekitar $60 \%$ dan di Swedia sekitar $72 \%$, sementara di Indonesia angkanya diperkirakan $55 \%$ perempuan usia produktif yang tersiksa oleh nyeri selama menstruasi. Angka kejadian nyeri menstruasi berkisar $45-95 \%$ di kalangan wanita usia produktif (Proverawati, 2009).

\section{METODE PENELITIAN}

Penelitian ini menggunakan desain penelitian kuantitatif analitik dengan pendekatan cross sectional. Populasi dalam penelitian ini adalah semua remaja putri kelas XI SMA Negeri 15 Palembang Tahun 2016 yang berjumlah 217 siswi. Sampel yang digunakan adalah sebagian remaja putrid kelas XI SMA Negeri 15 Palembang Tahun 2016. Yang didapatkan dengan teknik pengambilan sampel stratified random sampling.

Data primer yang diperlukan dalam penelitian ini meliputi status gizi, usia menarche dan dismenorhea primer yang diperoleh melalui wawancara langsung dengan responden dengan menggunakan kuesioner yang diberikan kepada responden.

Data akan dianalisis dengan menggunakan analisis univariat dan bivariat. Analisis univariat untuk melihat distribusi frekuensi dari masingmasing kategori variabel dan analisis bivariat bertujuan untuk melihat hubungan antara variabel independen (status gizi dan usia menarche) dan variable dependen (dismenorhea primer )dengan menggunakan uji statistik Chi Square.

\section{HASIL DAN PEMBAHASAN}

\section{Status Gizi}

Tabel 1. $\begin{aligned} & \text { Distribusi } \\
& \text { Responden }\end{aligned}$
\begin{tabular}{ccc} 
Status Gizi & $\mathbf{f}$ & $\%$ \\
\hline Tidak Normal & 42 & 56,0 \\
Normal & 33 & 44,0 \\
\hline Total & 75 & 100 \\
\hline
\end{tabular}

Berdasarkan tabel di atas, dapat diketahui bahwa dari 75 responden, yang memiliki status gizi tidak normal sebanyak 42orang $(56,0 \%)$, lebih banyak jika dibandingkan dengan reponden yang memiliki status gizi normal yaitu sebanyak 33 orang $(44,0 \%)$.

Status gizi yang rendah (underweight) atau status gizi yang lebih (overweight) selain akan mempengaruhi pertumbuhan, fungsi organ tubuh, juga akan menyebabkan terganggunya fungsi reproduksi.

\section{Usia Menarche}

Tabel 2. Distribusi Frekuensi Usia Menarche Responden

\begin{tabular}{ccc}
\hline Usia Menarche & f & \% \\
\hline Tidak Normal & 45 & 60,0 \\
Normal & 30 & 40,0 \\
\hline Total & 75 & 100 \\
\hline
\end{tabular}

Berdasarkan tabel di atas, dapat diketahui bahwa dari 75 responden, yang memiliki status usia menarche tidak normal sebanyak 45 orang $(60,0 \%)$, lebih banyak jika dibandingkan dengan reponden yang memiliki usia menarche normal yaitu sebanyak 30 siswi (40,0\%). 
Saat menarche terjadi lebih awal dari normal dimana organ-organ reproduksi belum berkembang secara maksimaldan belum siap untuk mengalami perubahan dan masih terjadi penyempitan pada leher rahim, maka akan timbul rasa sakit saat menstruasi.

\section{Kejadian Dismenorhea Primer}

\begin{tabular}{ccc}
$\begin{array}{c}\text { Tabel 3. Distribusi } \\
\text { Dismenorhea } \text { Primer }\end{array}$ & Kejadian \\
\hline Kejadian Dismenorhea Primer & f & $\%$ \\
\hline Ya & 61 & 81,3 \\
Tidak & 14 & 18,7 \\
\hline Total & 75 & 100 \\
\hline
\end{tabular}

Berdasarkan tabel 3, dapat diketahui bahwa dari 75 responden, yang mengalami kejadian dismenore primer sebanyak 61orang $(81,3 \%)$, lebih banyak jika dibandingkan dengan reponden yang tidak mengalami kejadian dismenorhea primer yaitu sebanyak 14 orang $(18,7 \%)$.

Dismenorhea primer terjadi beberapa waktu setelah menarche. Rasa nyerti timbul sebelum atau bersama-sama dengan menstruasi dan berlangsung untuk beberapa jam, walaupun pada beberapa kasus dapat terjadi sampai beberapa hari.

\section{Hubungan Status Gizi dengan Kejadian Dismenorhea Primer}

Pada tabel 4, didapatkan dari 42 responden yang mengalami kejadian dismenorhea primer dengan status gizi tidak normal sebanyak 38 responden $(90,5 \%)$, lebih banyak jika dibandingkan dengan responden yang tidak mengalami kejadian dismenorhea primer dengan status gizi tidak normal sebanyak 4 responden $(9,5 \%)$.

Tabel 4. Hubungan Status Gizi dengan Kejadian Dismenorhea Primer

\begin{tabular}{llrrrrr}
\hline & & \multicolumn{4}{c}{ Kejadian } \\
No & $\begin{array}{c}\text { Status } \\
\text { Gizi }\end{array}$ & \multicolumn{3}{c}{ Dismenorhea Primer } & Total \\
\cline { 3 - 6 } & & Ya & \multicolumn{3}{c}{ Tidak } & \\
\cline { 3 - 6 } & & $\mathbf{n}$ & \% & n & \% & n \\
\hline 1. & Tdk & 38 & 90,5 & 4 & 9,5 & 42 \\
& Normal & & & & & \\
2. & Normal & 23 & 69,7 & 10 & 30,3 & 33 \\
\hline & Jumlah & 61 & & 28 & & 75 \\
\hline
\end{tabular}

Berdasarkan hasil uji statistik dengan analisis Chi Square didapatkan $p$-value $=0,046$ lebih kecil dari $\alpha=0,05$ menunjukkan bahwa ada hubungan antara status gizi dengan kejadian dismenorhea primer. Dengan demikian hipotesis yang menyatakan bahwa ada hubungan antara status gizi dengan kejadian dismenorhea primer terbukti secara statistik.

Status gizi merupakan salah satu faktor resiko terjadinya dismenorhea primer, status gizi yang rendah (underweight) dapat diakibatkan karena asupan makanan yang kurang, termasuk zat besi yang dapat menimbulkan anemia. Anemia merupakan salah satu faktor yang menyebabkan kurangnya daya tahan tubuh terhadap rasa nyeri sehingga saat menstruasi dapat terjadi dismenorhea primer, sedangkan status gizi lebih (overweight) dapat juga mengakibatkan dismenorhea karena terdapat jaringan lemak yang berlebihan yang dapat mengakibatkan hiperplasi pembuluh darah atau terdesaknya pembuluh darah oleh jaringan lemak pada organ reproduksi wanita, sehingga darah yang seharusnya mengalir pada proses menstruasi terganggu dan mengakibatkan nyeri pada saat menstruasi (Kusmiran, 2011).

Hasil penelitian ini sejalan dengan penelitian yang dilakukan oleh Beddu (2013), tentang hubungan status gizi dan usia menarche dengan dismenorhea primer pada remaja putri di SMA Nasional Makassar, didapatkan hasil analisis variabel status gizi dengan menggunakan uji statistik Chi-square dengan pearson Chisquare test menunjukan nilai $p=0,008$, artinya terdapat hubungan yang bermakna antara status gizi dengan dismenorhea primer.

Hasil penelitian ini juga sejalan dengan penelitian yang dilakukan oleh Nasution (2013), tentang hubungan status gizi dengan kejadian dismenorhea primer pada remaja putri di SMA swasta Istiqlal Kecamatan Delitua Kabupaten Deli Serdang, didapatkan dari hasil uji Chisquare pada hubungan status gizi dengan dismenore primer diperoleh nilai $p=0,00$ $(\mathrm{p}<0,05)$, artinya terdapat hubungan yang signifikan antara status gizi dengan kejadian disminorhea primer.

Berdasarkan hasil penelitian serta teori yang ada dapat dibuat kesimpulan bahwa ada hubungan yang bermakna antara status gizi dengan kejadian dismenorhea primer. Jika nutrisi dan status gizi seseorang baik maka akan terhindar dari masalah dismenorhea. 


\section{Hubungan Usia Menarche dengan Kejadian Dismenorhea Primer}

Tabel 5. Hubungan Usia Menarche dengan Kejadian Dismenorhea

\begin{tabular}{|c|c|c|c|c|c|c|c|}
\hline \multirow{3}{*}{ No } & \multirow{3}{*}{$\begin{array}{c}\text { Usia } \\
\text { Menarche }\end{array}$} & \multicolumn{4}{|c|}{$\begin{array}{c}\text { Kejadian } \\
\text { Dismenorhea } \\
\text { Primer }\end{array}$} & \multirow{2}{*}{\multicolumn{2}{|c|}{ Total }} \\
\hline & & \multicolumn{2}{|c|}{ Ya } & \multicolumn{2}{|c|}{ Tidak } & & \\
\hline & & $\mathbf{n}$ & $\%$ & $\mathbf{n}$ & $\%$ & $\mathbf{n}$ & $\%$ \\
\hline 1. & $\begin{array}{l}\text { Tidak } \\
\text { Normal }\end{array}$ & 41 & 91,1 & 4 & 8,9 & 45 & 100 \\
\hline 2. & Normal & 20 & 66,7 & 10 & 33,3 & 30 & 100 \\
\hline & Jumlah & 61 & & 14 & & 75 & 100 \\
\hline
\end{tabular}

Pada tabel 5 didapatkan dari 45 responden yang mengalami kejadian dismenorhea primer dengan usia menarche tidak normal sebanyak 41 responden $(91,1 \%)$, lebih banyak jika dibandingkan dengan responden yang tidak mengalami kejadian dismenore primer dengan usia menarche tidak normal sebanyak 4 responden $(8,9 \%)$.

Berdasarkan hasil uji statistik dengan analisis Chi Square didapatkan $p$-value $=0,018$ lebih kecil dari $\alpha=0,05$ menunjukkan bahwa ada hubungan antara usia menarche dengan kejadian dismenorhea primer. Dengan demikian hipotesis yang menyatakan bahwa ada hubungan antara usia menarche dengan kejadian dismenorhea primer terbukti secara statistik.

Menarche merupakan perdarahan pertama kali dari uterus yang terjadi pada wanita di masa pubertas sekitar usia 12-14 tahun. Menarche merupakan perubahan yang menandakan bahwa remaja sudah memasuki tahap kematangan organ seksual dalam tubuh. Dimulainya menarche membuat organ seks sekunder tumbuh berkembang, seperti pembesaran payudara, mulai tumbuh rambut ketiak, panggul membesar dan juga mulai berkembangnya beberapa organ vital yang siap untuk dibuahi. Usia menarche bervariasi pada setiap individu dan wilayah tempat tinggal. Namun usia menarche dapat dikatakan normal apabila terjadi pada usia 12-14 tahun (Susanti, 2012).

Terdapatnya hubungan antar usia menarche terhadap kejadian dismenorhea primer dikarenakan saat menarche terjadi lebih awal dari normal maka alat reproduksi belum siap untuk mengalami perubahan dan masih terjadi penyempitan pada leher rahim, maka akan timbul rasa sakit saat menstruasi (Novia \& Puspitasari 2008).

Hasil penelitian ini sejalan dengan penelitian yang dilakukan oleh Pakaya (2013), tentang hubungan faktor risiko dengan kejadian dismenorhea primer pada siswi kelas VIII SMPN 6 Gorontalo, didapatkan dari hasil uji statistik Chi-square diperoleh nilai $p=0,004 \quad(\mathrm{p}<0,05)$, artinya terdapat hubungan yang signifikan antara usia menarche dengan kejadian dismenore primer. Hasil penelitian ini juga sejalan dengan penelitian yang dilakukan oleh Beddu (2013), tentang hubungan status gizi dan usia menarche dengan dismenorhea primer pada remaja putri di SMA Nasional Makassar didapatkan hasil analisis variabel usia menarche dengan menggunakan uji statistik Chi-square dengan pearson Chi-square test menunjukan nilai $p=0,006$, artinya terdapat hubungan yang bermakna antara usia menarche dengan dismenorhea primer.

Berdasarkan hasil penelitian serta teori yang ada dapat dibuat kesimpulan bahwa ada hubungan yang bermakna antara usia menarche dengan kejadian dismenorhea primer.

\section{SIMPULAN}

1. Responden yang memiliki status gizi tidak normal sebanyak 42 orang $(56,0 \%)$, responden yang memiliki status usia menarche tidak normal sebanyak 45 orang $(60,0 \%)$ dan responden yang mengalami kejadian dismenorhea primer sebanyak 61 orang $(81,3 \%)$.

2. Ada hubungan status gizi dengan dismenorhea primer pada remaja putri kelas XI SMA Negeri 15 Palembang Tahun 2016 ( $\rho$-value $=0,046)$.

3. Ada hubungan usia menarche dengan dismenorhea primer pada remaja putri kelas XI SMA Negeri 15 Palembang Tahun 2016 $(\rho$-value $=0,018)$.

\section{SARAN}

Perlu adanya kerjasama antara pihak sekolah dengan tenaga kesehatan setempat untuk meningkatkan promosi kesehatan tentang dismenorhea primer, faktor resiko penyebab dan cara mengatasinya. Petugas UKS dibekali dengan pengetahuan dan keterampilan tentang cara-cara mengurangi nyeri haid agar siswi-siswi yang mengalami dismenorhea saat sedang berada di sekolah mendpaatkan perawtaan dan penanganan dengan tepat. 


\section{DAFTAR PUSTAKA}

Beddu. 2013. Hubungan Status Gizi Dan Usia Menarche Dengan Desmenore Primer Pada Remaja Putri di SMA Nasional Makassar. Jurnal. The Southeast Asian Journal of MidwiferyVol. 1, No.1, Oktober 2015, Hal: 16-21.

Daftary., Patky. 2008. Dasar-dasar Obstetri \& Ginekologi. Jakarta: Hipokrates.

Dewi. 2012. Biologi Reproduksi.Yogyakarta: Pustaka Rihama.

Kusmiran. 2011. Kesehatan Reproduksi Remaja dan Wanita. Bandung: Salemba Medika

Nasution. 2013. Hubungan Status Gizi Dengan Kejadian Dismenore Primer Pada Remaja Putri di SMA swasta Istiqlal Kecamatan Delitua Kabupaten Deli Serdang. Jurnal Universitas Sumatera Utara.

Novia, Puspitasari. 2008. Faktor Risiko yang Mempengaruhi Kejadian Dismenore
Primer. Jurnal Departemen Biostatistika dan Kependudukan Fakultas Kesehatan Masyarakat Universitas Airlangga.

Pakaya. 2013. Hubungan Faktor Resiko Dengan

Kejadian Dismenore Primer Pada Siswi Kelas VIII SMPN 6 Gorontalo. Jurnal Universitas Negeri Gorontalo.

Proverawati. 2009. Menarche; Menstruasi Pertama Penuh Makna.Yogyakarta. Nuha Medika.

Rosenthal. 2013. Pedoman untuk Wanita Revolusi Terapi Hormon. http://Proquest.umi.com (Diakses tanggal 9 April 2016).

Susanti. 2012. Faktor Resiko Kejadian Menarche Dini pada Remaja di SMP N 30 Semarang. Journal of Nutrition College. 1 (1) : 38640. 